\title{
Training for minor surgery in general practice during preregistration surgical posts
}

\author{
Mike Pringle, John Hasler, Paolo De Marco
}

\begin{abstract}
Objective-To study the teaching of minor surgery to preregistration house officers in surgery and their confidence in their skills.

Design-Questionnaire survey of consultants and vocational trainees.

Setting-Trent, Oxford, and East Anglian Regional Health Authorities.

Subjects-All consultant surgeons $(n=148)$ with preregistration house officers on their firm and all first year vocational trainees in general practice $(\mathrm{n}=165)$.

Main outcome measures-Time spent teaching minor surgery to preregistration house officers; source of teaching; trainees' confidence in their skills in $\mathbf{1 5}$ minor surgical procedures and degree of confidence that consultants expected their junior house officers to achieve.
\end{abstract}

Results-137 (93\%) consultants and $139(84 \%)$ vocational trainees replied; 131 of the consultants' replies and all the trainees' replies were analysable. Only 14 consultants had a curriculum for teaching junior house officers, and 90 offered less than four hours' teaching a week. Only 11 trainees thought that their firm had had a curriculum, and 102 reported having received under two hours' teaching a week. The consultants indicated that they did most of the teaching, but the trainees reported having received most of their teaching from junior registrars. Seventy nine consultants attempted to teach minor surgery. They expected their junior house officers to acquire greater confidence in their skills in minor surgery than did the other consultants, but overall the confidence expected was low. The trainees were more confident than the consultants expected them to be, but overall confidence was still low. Those who had received more teaching were significantly more confident.

Conclusions-The educational potential of the post of preregistration house officer in surgery seems underexploited, particularly with regard to teaching skills in minor surgery.

\section{Introduction}

Minor surgery done in general practice has been shown to be convenient for patients, ${ }^{1}$ practical,${ }^{23}$ and cost efficient ${ }^{2}$ with a low rate of infection, ${ }^{3}$ but studies have usually been done by general practitioners with a special interest in minor surgery. Under the new contract for general practitioners ${ }^{4}$ a fee will be payable for each "session" of minor surgery, which consists of at least five surgical procedures. ${ }^{5}$ This innovation raises questions of competence and training. ${ }^{6}$

Established principals in general practice have been admitted to their family health services authority's minor surgery list on the basis of their experience and compliance with guidelines agreed by the Royal College of General Practitioners and Royal College of Surgeons. Few practitioners, however, have considered minor surgery to be integral to their role, ${ }^{78}$ and even fewer have actually undertaken it. ${ }^{9}$ In future most doctors seeking admission to the list will be those completing their vocational training. Minor surgery could be taught during various components of vocational training, but there is no standard mix of hospital posts that all trainees follow.

As a preregistration surgical post is a prerequisite for full registration with the General Medical Council it would seem possible, and appropriate, for skills in minor surgery to be taught in such posts. Though doubt has recently been cast on the extent and quality of teaching in the hospital component of vocational training, ${ }^{1011}$ nothing is known about the teaching of basic skills such as minor surgery in the one surgical job undertaken by all doctors. We therefore examined the teaching of minor surgery in preregistration surgical posts and examined the implications for vocational training.

\section{Subjects and methods}

We chose three NHS regions-Trent, Oxford, and East Anglian - for study and identified all consultant surgeons with preregistration posts in their firm through the personnel offices of the regional health authorities. In May and June 1990 we sent each consultant a questionnaire with a covering letter; nonresponders were sent one reminder.

We identified vocational trainees in the first year of a formal three year vocational training scheme from the records of the regional advisers and course organisers. We chose these doctors because they were most likely to have recently completed a preregistration post in surgery and were expressing a clear intention to enter general practice. We sent all such trainees a questionnaire that was similar in content to the consultants' questionnaire; non-responders were sent one reminder.

The data were entered into a computer and analysed with the statistical package for the social sciences.

The consultants' responses were based on the junior jobs in their firm in general, and many of their junior house officers would have moved to other regions or entered hospital specialties. A telephone survey of vocational training schemes in Trent showed that just over half of trainees had done their junior surgical job in Trent. Some of the responses from the vocational trainees therefore relate to experience gained outside the regions in this survey.

\section{Results}

We identified 148 consultant surgeons, of whom 137 $(93 \%)$ replied. A total of 131 responses were analysable; the six other consultants chose to reply with letters rather than complete the questionnaire. Of the 165

Correspondence to: 
TABLE I - Amount of teaching time that consultant surgeons believed they offered

preregistration house officers and that vocational trainees believed they had received

Consultant Vocational Teaching surgeons trainees $\begin{array}{lll}\text { Teaching } & \text { surgeons } & \text { trainees } \\ \text { time }(\mathrm{h}) & (\mathrm{n}=128) & (\mathrm{n}=136)\end{array}$

$\begin{array}{crr}\text { None } & 1 & 8 \\ <1 & 5 & 31 \\ 1- & 30 & 63 \\ 2- & 54 & 25 \\ 4- & 20 & 4 \\ \geqslant 6 & 18 & 5\end{array}$

vocational trainees identified, 139 (84\%) replied; all their responses were analysable. The overall response rate was higher in the Oxford region (94/100 replies; $94 \%)$ than in Trent $(112 / 135 ; 83 \%)$ and East Anglian $(64 / 78 ; 82 \%)$. All but one of the consultant surgeons and half $(68)$ of the vocational trainees were men. The mean age of the surgeons was 49.0 years and that of the trainees $26 \cdot 1$ years.

The respondents were asked to indicate how much teaching they offered preregistration house officers in an average week or how much they had received in such a post (table I). The consultants indicated that they offered more teaching than the trainees reported having received (Mann-Whitney $U$ test, $\mathrm{p}<0 \cdot 0001$ ). Fourteen out of 129 consultants had a curriculum for teaching their preregistration house officers, and 11 of the 139 vocational trainees recorded that there had been a curriculum. The respondents' perception of who did the teaching differed (table II): the vocational trainees scored the input from the consultant and senior house officer lower and the input from the junior registrar higher than did the consultants.

The consultants were asked how confident in their skill in doing minor surgical procedures the junior house officers on their firm should become; the procedures were those eligible for payment under the new general practitioner contract. ${ }^{5}$ The vocational trainees were asked how confident they were in their skills in these procedures. The response for each procedure was scored from 1 for "very confident" to 4 for "not experienced" (therefore no confidence), and the scores were then summated to give an overall score indicating confidence in minor surgery (table III). The trainees were significantly more confident in their skills (Mann-Whitney U test, $\mathrm{p}=0.007$ ) than the consultants expected them to be.

Altogether 120 out of 134 vocational trainees intended to do minor surgery when in practice, but this intention was not significantly related to overall confidence in their skills in minor surgery. The more teaching time that they had had as preregistration house officers in surgery the higher was the trainees' assessment of their confidence in their skills in minor surgery (MannWhitney $U$ test, $p=0 \cdot 006)$. Only 79 out of 129

TABLE II - Source of training received by preregistration house officers in surgery as indicated by consultant surgeons and vocational trainees

\begin{tabular}{|c|c|c|c|c|c|c|}
\hline \multirow[b]{2}{*}{ Teacher } & \multicolumn{3}{|c|}{$\begin{array}{l}\text { Consultant surgeons } \\
\qquad(\mathrm{n}=130)\end{array}$} & \multicolumn{3}{|c|}{$\begin{array}{l}\text { Vocational trainees } \\
\qquad(\mathrm{n}=136)\end{array}$} \\
\hline & Most & Some & None & Most & Some & None \\
\hline Consultant & 29 & 99 & 2 & 20 & 84 & 32 \\
\hline Senior registrar & 16 & 58 & 56 & 16 & 43 & 77 \\
\hline Junior registrar & 23 & 74 & 33 & 50 & 39 & 47 \\
\hline Senior house officer & 16 & 74 & 40 & 13 & 44 & 79 \\
\hline Other junior house officer & & 5 & 125 & & 13 & 123 \\
\hline Nurses & & 6 & 124 & 3 & 3 & 130 \\
\hline
\end{tabular}

consultants attempted to teach minor surgery to their junior house officers, and they expected their juniors to be more confident than did the other consultants (Mann-Whitney U test, $\mathrm{p}=0 \cdot 01$ ).

\section{Discussion}

If the payments for minor surgery by general practitioners under the new contract are to result in an increase in services to patients and a reduction in hospital waiting lists then more-probably most general practitioners will need to do minor surgery. After completing their post as a preregistration house officer two thirds of vocational trainees work as senior house officers in accident and emergency or surgical departments ${ }^{12}$ and some will gain experience in minor surgery in rheumatology and dermatology departments as well as in their year in general practice.

The common surgical experience of all general practitioners is their time as a preregistration house officer. Both responses to the questions in this study and written comments indicated clearly that many consultant surgeons view preregistration not as training posts but as service posts. Only $11 \%$ had a teaching curriculum, and $70 \%$ offered teaching for less than four hours a week. Though the consultants reported that they did most of the teaching, the vocational trainees recorded having received less teaching than the consultants had reported and this predominantly from junior registrars. When the consultants rated their junior house officers' confidence in their skills in minor surgery at the end of their post the $57 \%$ of surgeons who tried to teach minor surgery gave their juniors a higher rating than did those who did not teach it.

Some consultants commented that the list of minor surgical procedures eligible for payment under the new contract included several procedures that were inappropriate: the incision of a thrombosed haemorrhoid, excision of a ganglion, and ligation of varicose veins were not suitable to be performed in primary care. It seems that a surgical consensus was not sought when the list of procedures was compiled. The list has subsequently been modified by the removal of excision of ganglions and ligation of varicose veins.

Most consultants reported that their junior house officers would not gain experience in nine of the 15 procedures on the list. Though the vocational trainees were more confident in their skills overall than the consultants were, most still said that they had not gained any experience of six of the 15 procedures, and in the highest rated skill-excision of a sebaceous cyst - only a third felt very confident. Clearly a few of the procedures would normally be done in other hospital departments; most, however, could be regarded as general surgical procedures.

TABLE III - Degree of confidence in their skill in 15 minor surgical procedures that consultant surgeons expected preregistration house officers on their firm to acquire and that vocational trainees believed they had acquired

\begin{tabular}{|c|c|c|c|c|c|c|c|c|}
\hline \multirow[b]{2}{*}{ Minor surgical procedure } & \multicolumn{4}{|c|}{ Consultant surgeons $(n=130)$} & \multicolumn{4}{|c|}{ Vocational trainees $(n=139)$} \\
\hline & $\begin{array}{c}\text { Very } \\
\text { confident }\end{array}$ & $\begin{array}{c}\text { Moderately } \\
\text { confident }\end{array}$ & $\begin{array}{l}\text { Not very } \\
\text { confident }\end{array}$ & $\begin{array}{c}\text { Not } \\
\text { experienced }\end{array}$ & $\begin{array}{c}\text { Very } \\
\text { confident }\end{array}$ & $\begin{array}{l}\text { Moderately } \\
\text { confident }\end{array}$ & $\begin{array}{l}\text { Not very } \\
\text { confident }\end{array}$ & $\begin{array}{c}\text { Not } \\
\text { experienced }\end{array}$ \\
\hline Intra-articular and periarticular joint injection & 1 & 5 & 6 & 118 & 10 & 29 & 38 & 62 \\
\hline Varicose vein injection & 3 & 16 & 19 & 92 & 4 & 6 & 18 & 111 \\
\hline Haemorrhoid injection & & 11 & 36 & 83 & $i$ & 8 & 20 & 110 \\
\hline Joint aspiration & & 6 & 12 & 112 & 19 & 42 & 26 & 52 \\
\hline Aspiration of hydrocele & 7 & 37 & 32 & 54 & 15 & 27 & 26 & 71 \\
\hline Incision of abscess & 15 & 62 & 32 & 21 & 39 & 56 & 25 & 19 \\
\hline Incision of thrombosed haemorrhoid & 4 & 14 & 21 & 91 & 4 & 7 & 21 & 107 \\
\hline Excision of sebaceous cyst & 27 & 51 & 25 & 27 & 42 & 53 & 18 & 26 \\
\hline Excision of lipoma & 24 & 48 & 27 & 31 & 34 & 46 & 27 & 32 \\
\hline Skin biopsy & 28 & 51 & & 29 & 35 & 49 & 18 & 37 \\
\hline Excision of ganglion & 2 & 2 & 22 & 108 & 2 & 9 & 25 & 103 \\
\hline Removal of toenail & 14 & 26 & 39 & 51 & 25 & 26 & 26 & 62 \\
\hline Curettage and cautery & 7 & 11 & 19 & 93 & 19 & 28 & 25 & 67 \\
\hline Ligation of varicose veins & 2 & 14 & 26 & 88 & 5 & 8 & 29 & 97 \\
\hline Nasal cautery & & & 1 & 129 & 7 & 9 & 19 & 104 \\
\hline
\end{tabular}


This survey covered three large regions of the NHS, and the responses from each region were similar for the two groups of doctors studied. We therefore consider the consultants to be representative of consultant surgeons as a whole and the vocational trainees to be representative of former preregistration house officers in surgery.

Now that the new contract for general practitioners is in operation doctors will have to find the most appropriate way of providing training in minor surgery, which $90 \%$ of the vocational trainees in this survey intended to perform. With the exception of injections into joints and aspirations most of the procedures could logically be mastered during a preregistration surgical post. The alternative is for the training to be provided in accident and emergency and dermatology departments, which for many vocational trainees would require special attachments. The family health services authorities will also require some form of certification, which will in turn require formal education and supervision. It is important that doctors organising courses on vocational training and hospital consultants urgently devise a satisfactory solution to this problem.
We thank all the consultants and vocational trainees who responded to our questionnaire, especially those who added comments. We funded the study privately.

1 Sharman J. Patient's response to a general practice minor surgery service. Practitioner 1986;230:27-9.

2 Brown JS. Minor operations in general practice. BMF 1979;i: 1609-10.

3 Wall DW. Minor surgery: one general practitioner's experiences. J R Coll Gen Pract 1982;32:480-2.

4 Department of Health and Welsh Office. General practice in the National Healt Service: a new contract. London: Department of Health and Welsh Office, 1989.

5 Department of Health. Statement of fees and allowances. London: DoH, 1990

6 Milne R. Minor surgery in general practice. Br f Gen Pract 1990;40:175-6.

7 Whitfield $M$, Bucks R. General practitioners' responsibilities to their patients. BMF 1988;297:398-400.

8 Whitfield M, Grol R, Mokkink H. General practitioners' opinions about their responsibility for medical tasks: comparison between England and the responsibility for medical tasks: compic

9 Wall DM. A review of minor surgery in general practice in the United Kingdom. Fam Pract 1987; 4:322-9.

10 Kealey K. An evaluation of the hospital component of general practice vocational training. Brf Gen Pract 1990;40:409-14

11 Styles WMcN. General practice training in the hospital. $\mathrm{Br} f \mathrm{Gen}$ Pract 1990;40:401-2.

12 Styles WMcN. Analysis of the hospital experience completed by general practitioner trainees in 1984-7. $\mathcal{F} R$ Coll Gen Pract 1989;39:96-7.

(Accepted 21 February 1991)

\section{MIRROR OF MEDICINE}

Because the Fournal's circulation was principally to BMA members, it was difficult for it to increase its income or effect economies simply by raising its price or reducing its print run. Indeed, its financial problems were exacerbated by the fact that additional circulation, if it came through growing BMA membership rather than non-member subscriptions, increased costs without increasing income. By the same token, falling circulation could make the Fournal more profitable. When, in 1962, the BMA faced the secession of its Australian branches and the resignation of a large proportion of its Australian members, the Fournal could contemplate a considerable fall in its costs. For the Association, on the other hand, secession meant a large loss of income.

In 1951, notwithstanding howls of protest from the pharmaceutical companies, advertising rates were raised $10 \%$; it was also decided that more could be done to increase fournal sales abroad. But even with the new rates, and even if higher sales targets were achieved, deficits looked certain to continue. In any case the state of the Fournal's finances was not the only problem. Indeed, for Clegg it was a relatively minor one, though he was concerned that economies could affect the quality of the fournal's content if they entailed appreciable page reductions. But his main worry was the fournal's business management and, specifically, the extent to which he had become embroiled in it. Even before the postwar growth in BMA publishing Clegg had found himself sharing, with the Board of Directors' secretary, many of the Fournal's business decisions. Because there was no adequate business management structure, Clegg had become, to his increasing disgruntlement, "more and more involved in the business side of the work," in fact, not only "the Editor of a weekly journal but the executive head of a publishing house." In these circumstances both he and the Publishing Subcommittee recommended to Council that there should be a thorough and "urgent" reorganisation of business management. Council agreed.

Although there was unanimity on the need for change, there were many contrasting views about what should be done. One set of suggestions focused on cost cutting. O C Carter, who was chairman of both the fournal Committee and the Publishing Subcommittee, and no friend of Clegg, felt that the fournal could save money if its average size were reduced by four pages an issue. Another suggestion was to ascertain how many BMA members actually wanted the fournal so that circulation might be trimmed accordingly. The fournal Committee resolved in favour of investigating the financial implications of a circulation cut of 20000-30000. As for management, Carter favoured far closer supervision of Fournal affairs by officials of the Association.

Most of these ideas, especially for closer supervision by the BMA, were anathema to Clegg, though he was willing to follow the example of the Swedish Medical Association and discontinue supplying the fournal as an automatic benefit of Association membership. This would mean that it would go only to those who specifically subscribed to it. Clegg always believed that people did not appreciate a benefit received free of charge. By making the fournal a subscription periodical he felt he would gain release from many of those who complained about it. But in general Clegg held very different ideas from the fournal Committee. He preferred to save paper not by trimming every issue, which would inevitably lead to the loss of much valuable material, but by jettisoning the annual educational number (which dated from Ernest Hart's day and had recently returned after its wartime suspension). A more revolutionary suggestion came in the resurrection of an idea which had been floated in 1948, but had then come to nothing. This was for a fixed percentage of BMA subscription income to be allocated to the fournal. This, Clegg believed, would exercise an important psychological function in that it would end the perception of the fournal as a loss making branch of the BMA. As for the running of the publishing business, he thought that the time had come to take it out of the hands of part time medical men acting as amateur businessmen and place it in professional hands. At first Clegg favoured the appointment of a full time business manager, though he had second thoughts when he learnt what this could cost.

From Mirror of Medicine: A History of the BMF by P W J Bartrip. Published jointly by the $B M \mathcal{F}$ and Oxford University Press; BMA members' price UK $£ 29$, overseas $£ 33$, including postage. Obtainable from the Publishing Manager, $B M \mathcal{F}$, PO Box 295, London WC1H 9TE. Non-members UK $£ 35$. Obtainable from OUP Distribution Services, Saxon Way West, Corby, Northamptonshire NN18 9ES. 